\title{
Erosion of A Developmental State: A Case Study of South Korea's Semiconductor Industry
}

\author{
JIYOUNG KIM** AND EUN MEE KIM ${ }^{* *}$
}

This paper examines the development of South Korea's semiconductor industry from its inception in the 1960s to the present, focusing on erosion of the developmental state and changes in the state-business relationship. The semiconductor industry in South Korea is another showcase of South Korea's remarkable economic development in the $20^{\text {th }}$ century. However, showing that it was not the state sector, but the private business groups that took the initiatives and played a leading role in the development of the semiconductor industry in South Korea, the paper challenges the developmental state theory's contention that the developmental state was most pronounced in South Korea even among its peers in East Asian newly industrializing countries.

Keywords: East Asia, South Korea, Developmental states, Industrial policy, State-business relationship, Semiconductor industry

First Author, Jiyoung Kim, Graduate Student, Department of Political Science; University of California, Irvine, CA 92697, USA; Tel: 1-949-856-1854; Fax: 1-949-824-8762; E-mail: jiyoungk@uci.edu *Eun Mee Kim, Dean, Graduate School of International Studies; Ewha Womans University, 11-1 Daehyun-dong, Seodaemun-gu, Seoul, 120-750, South Korea; Tel: 82-2-3277-3669; Fax: 82-2-3648019; E-mail: emkim@ewha.ac.kr 


\section{INTRODUCTION}

$\mathrm{T}$ he semiconductor industry in South Korea is another showcase of South Korea's remarkable economic development in the $20^{\text {th }}$ century. Following the unprecedented rapid industrialization in the region, which included Taiwan, Singapore, and Hong Kong, South Korea catapulted in the world economy with its export products - starting from stuffed toys and wigs in the 1960s to automobiles and home electronics products by the 1990s. In particular, behind the success of these export products stood the strong developmental state and the large business groups, or the chaebol.

However, the South Korean semiconductor industry's rise to one of the world's leading chipmakers was different. Its rise challenged the developmental state theory's contention that the developmental state was most pronounced in South Korea even among its peers in East Asian newly industrializing countries (NICs), and clearly demonstrated the changing nature of state-business relations in South Korea in light of the changing global marketplace. Furthermore, it challenged the notion of Third World development that the late developing economies could not attain the level of technological sophistication in advanced high technology and capital-intensive sectors such as semiconductors.

Through a case study of the South Korea's semiconductor industry, this paper highlights the erosion of the developmental state and criticizes the limitations of the state-centered approach. We argue that the traditional developmental state framework fails to capture the dynamic nature of state-business relationships and its changes over time. Like its Taiwanese counterpart, South Korea's semiconductor industry started mainly as subsidiaries of foreign multinational corporations (MNCs), producing low technological semiconductor devices. By the early 1990s, however, South Korea became the leading Dynamic Random Access Memories (DRAM) maker and the third largest semiconductor producer in the world with sophisticated technologies enough to make cutting-edge memory chips, such as 256M DRAMs and Rambus. A true leapfrogging began in the early - to mid - 1980s when three major South Korean chipmakers - Samsung, Hyundai, and Goldstar (renamed as LG in 1999), saw the future in this industry and took measures to transform into high-tech companies. These decisions were made primarily by the chaebol themselves without significant governmental guidance or support. In this study, we focus on the period when the South Korean semiconductor industry began to transform from a simple, labor intensive sector to a high-tech, capital-intensive one, highlighting the leading role of the chaebol in this process of transition.

Unlike South Korea's other major industries such as automobiles and steel, semiconductors were not a target industry during the Park Chung Hee government (1962-79). It was not until Samsung's highly publicized success in developing 256M DRAM in the mid-1980s when the state finally started to take the industry 
more seriously. However, even after Samsung's remarkable take-off, the role of the state in general has been restricted to coordinating, regulating, and helping the chaebol, rather than directing and leading the latter. In explaining the causes of the erosion of the developmental state, this paper examines the broader contextual factors including the end of the Cold War, increasing trade tension with the U.S., pressure for liberalization, democratization, and rising wages. We argue that all of these structural factors, as well as the growth of the chaebol itself, limited state intervention in the market and eventually brought about the erosion of the South Korean developmental state since the 1980s.

This paper examines the development of the semiconductor industry in South Korea from its inception in the 1960 s to the present. Using the developmental state framework, we examine the case of the South Korean semiconductor industry and trace the changing state-business relationship highlighting the limited role of the state in the development of the semiconductor industry.

\section{RETHINKING THE DEVELOPMENTAL STATE FRAMEWORK}

In explaining the rapid economic development path of the East Asian NICs, the developmental state approach has gained wide recognition. Efficient state intervention in the market through various industrial policies seriously challenged the neo-classical arguments. In particular, the strong state with relative autonomy from society and efficient bureaucracy are widely recognized as the main characteristics of the developmental state (Johnson 1982; Haggard and Cheng 1987). However, through a case study of South Korea's semiconductor industry, this paper tells a different story from the traditional developmental state approach that heavily focused on the state-led economic development in East Asia. Instead of leading the private sector, this study shows that the state played a limited role in the development of South Korea's semiconductor industry. Early studies from the developmental state approach adopted a static view in analyzing the role of the state and did not adequately deal with the changes in the nature of the developmental state or its erosion over time. ${ }^{1}$ Recognizing these limitations, this paper examines factors that brought about changes in the developmental state, with a special focus on the structural causes of erosion and the state-business relationship.

Many studies on South Korea's high-tech industry highlighted the role of the state. For example, Robert Wade (1990) argued that the South Korean state played a critical role in the development of the high-tech industry. It built basic research and development (R\&D) facilities, induced foreign direct investment (FDI), and directly promoted the high-tech industry through governmental planning and research institutes. ${ }^{2}$ However, other studies, which focus more specifically on South Korea's semiconductor industry, present a different 
view about the state. S. R. Kim (1996) traced the historical development of the South Korean semiconductor industry and criticized the South Korean state for its lack of support for local chipmakers. The author also argued that the success of the South Korean semiconductors did not come from the remarkable role of the "developmental state," but it was rather the result of complex interactions between the world market, the state, and chaebols.3

Similarly, S. G. Hong (1997)'s comparative study of the Taiwanese and the South Korean semiconductor industries highlight that unlike other heavy and chemical industries, which was intensively promoted by the state during the 1970s, the South Korean semiconductor industry was mainly led by the private sector, especially the three South Korean chaebols: Samsung, Goldstar, and Hyundai. He further showed that state intervention in this sector was less in South Korea than in Taiwan. This finding is rather contradictory to the general understanding of these two East Asian countries. It is commonly believed that the Taiwanese economy is closer to the liberal market economy than that of South Korea. 4

In his case study of South Korea's high-tech sector, Linsu Kim (1993) also focused on the role of the private sector. According to the author, "with the technological network, high-caliber scientific and engineering human power, and ambitious R\&D investment, chaebol took a leading role in moving toward the technological frontier" $(1993,376)$. He further argued that chaebol dominance in South Korea's high-tech industries was in a sense inevitable due to the high risk and heavy initial cost involved. These big chaebol companies were able to mobilize a large amount of capital and resources in a relatively short period of time (in many cases through cross financing), which were not feasible in the case of small - and medium sized companies. We will come back to this point later.

Other studies focus more on the technological development achieved by the South Korean chaebol. Focusing on the electronics industry, Hobday (1995) analyzed the strategies that the South Korean firms adopted in order to learn high technology and achieve innovative development. According to the author, FDI, joint venture, and informal channels such as hiring foreign engineers and recruiting experts trained in MNCs were their main tactics. Hobday (1995) also emphasized the local firms' own R\&D efforts. Likewise, using the U.S. patent data and publications, Choung et al. (2000) traced the evolution of technological capabilities of South Korean semiconductor firms and concluded that they have successfully deepened their technological capabilities.

However, though these studies correctly point out the limitations of the state-centered approach by focusing on the spontaneous role of the private sector, they do not adequately deal with the factors that brought about the erosion of the developmental state. Also, we see that further efforts to link the case of South Korea's semiconductor industry to a larger picture of the developmental state model are needed. Recognizing the erosion of the developmental state and the 
growing impact of the business sector, this paper analyzes the causes of the erosion as well as the nature of the state-business relationship in the development of South Korea's semiconductor industry.

Then, what are the theoretical implications of erosion of the developmental state? First of all, this paper assumes that the concept of the developmental state and its relationship with other social actors, including the business groups, are not static. Therefore, in order to correctly understand the nature of the developmental state, we need to first focus on the changing role and dynamics of the developmental state. Arguing that the nature of the developmental state is unstable and contradictory, E. M. Kim (1997), for instance, traced the development of state-business relations in South Korea. According to this study (E. M. Kim 1997), the developmental state has a finite goal, and the rising of tension between the state and business sector is inevitable as the economy develops. Therefore, the contradiction in the developmental state lies in the fact that "the autonomy of the state will face increasing erosion if it is successful" (E. M. Kim 1997, 46), and the author concluded that the "strong state" perspective "failed to perceive that state power changes over time and differs between sectors: and that other actors, such as the chaebol in Korea, have also played a crucial role in economic development" (E. M. Kim 1997, 105).

Many studies about the South Korean chaebol and its relationship with the government pointed out the complex bargaining process between the state and the private sector (e.g., Haggard and Moon 1990; E. M. Kim 1997; Moon 1988). All of these studies questioned the "autonomy" of the South Korean state from the business groups, especially the chaebol, arguing that in many occasions, state intervention in South Korea had a more specific "political source than the autonomous preferences of strong state officials" (Doner 1992, 426). For instance, Haggard and Moon (1990) argued that the policy making process in South Korea has been highly constrained by the chaebol since the ruling party was financed by the "political taxes" paid by the chaebol. In fact, the state-chaebol relationship in South Korea has been in many respects, cooperative rather than state-dominant. Even during the height of the authoritarian Park regime, the state needed these big business groups in order to pursue its industrial policies and maintain its political power and the chaebol grew and diversified their businesses based on favorable state policies including low interest rates, licenses, and subsidies.

Indeed, the traditional developmental state approach failed to properly analyze the impact of the private sector on the state. The influence of chaebol on the state economic policy-making grew over time as these giant business groups became too big to be controlled by the state. For example, while recognizing the importance of the state institution in shaping the industrial structure of South Korea and Taiwan, K. J. Fields (1995) maintained that the government-business relationship in South Korea is increasingly "not one of dependence, as 
it once was $\cdots$ but one of interdependence or symbiosis" (1995, 102).

Embedded Autonomy (1995) by Peter Evans is one of the pioneering works that highlighted the different types of state roles and the dynamic relationship between the state and business groups. As the main characteristics of the developmental state, he emphasized the embeddedness and autonomy. ${ }^{5}$ Comparing state roles in the high tech industry in India, Brazil, and South Korea, Evans (1995) correctly argued that the question should focus on 'what kind' of state intervention rather than 'how much.' The author distinguished the different role of the state as "custodian," "demiurge," "midwifery," and "husbandry" 6 and suggested that the sectoral characteristics of each industry determine what state role is likely to work. He argued that the South Korean state is closer to the ideal developmental state model, and that it contributed to a successful growth of its high tech sector. However, Evans (1995) also recognized the irony of state intervention arguing that successful midwifery roles of the state eventually leads to the growth of the private sector and the new internationalization of the local firms.

In the following sections, we will first briefly cover the growth and characteristics of the semiconductor industry in South Korea. Then we will provide a more in-depth discussion of chaebol-led development of the industry and the erosion of the developmental state. According to Evans (1995), the midwifery role of the state in the South Korean electronics industry eroded over time and the role of 'policing' rather than 'promoting' became a central task of the state. Largely agreeing with his discussions of the erosion of the developmental state, however, we further argue that the South Korean state's "midwifery" role and the following "husbandry" role were limited even in the early stage of the development in the case of the semiconductor industry.

In fact, a number of studies of the South Korean industrial development focus heavily on the Park Chung Hee regime when the role of the developmental state was most pronounced. Therefore these studies fail to grasp the changing dynamic of the state-business relationship beyond the early stage of industrial development and tend to view the developmental state as static. Furthermore, there have not been many attempts to adopt an industry-specific analysis. Most studies of the South Korean industrial development focus on a specific time period rather than a particular industry, and therefore largely ignore the sectoral characteristics. Also, despite its success and importance in the national economy, there are relatively few in-depth studies about South Korea's semiconductor industry. Furthermore, most of these studies fail to link the case to a larger developmental state model. Recognizing these shortcomings, we examine the development of the South Korean semiconductor industry focusing on the state-business relationship, provide a "different" story about South Korea's industrialization, and contribute to broader theoretical discussions about the developmental state. 


\section{AN OVERVIEW OF THE SEMICONDUCTOR INDUSTRY IN SOUTH KOREA}

The semiconductor industry is the core electronics sector, leading other high-tech and electronic products. ${ }^{7}$ The semiconductor industry largely includes semiconductor manufacturing, devices, and material industries, and has following characteristics: (1) it requires a large investment in infrastructure and $\mathrm{R} \& \mathrm{D}$, which discourages many developing countries from promoting this industry; (2) technological cycle of the industry is very short (especially for the DRAMs) and the rapid technological upgrading is crucial to the success of the industry, which results in high-risk in this sector; (3) it is one of the most representative high-tech and knowledge-intensive industries; and (4) it is an important pilot industry that leads the development of other electronics industries.

As David Smith (1997) correctly pointed out, it would be hasty to conclude that South Korea achieved a genuine technical innovation in its high-tech industry. Furthermore, the development has been highly unbalanced toward the memory sector, especially the DRAMs, and in terms of the non-memory sector, South Korea is far behind the United States and Japan. ${ }^{8}$ While recognizing these limitations, we emphasize that South Korea's semiconductor industry, along with the Taiwanese counterpart, has been a successful case where a developing country has managed to compete effectively with advanced nations, contributing to the country's industrial transformation efforts toward the high-tech industry. As Table 1 shows, all of the South Korea's major chipmakers became the world's leading semiconductor firms (at least in the memory sector) by the late 1990s and the semiconductors have been seen as the most competitive product in South Korea. 9

Like the Taiwanese semiconductor industry, South Korea's semiconductors started with labor-intensive, low technological semiconductor devices in the mid-1960s and its scale and level of technology was very limited during this early stage. By the late 1990s however, Samsung and Hyundai dominated about 40 percent of the world's DRAM market and the South Korean firms became the world's leading DRAM makers (see Table 2). Such a rapid development also went hand in hand with technological development in memory chips. After succeeding in the development of 64K DRAM in 1983, Samsung developed 1G DRAM in 1996, and in 1999, Samsung succeeded in developing and producing $256 \mathrm{M}$ DRAM and Rambus (http://www.sec.co.kr). ${ }^{10}$

The percentage of the semiconductor industry in the whole electronics sector in South Korea increased from three percent in 1970 to 16.9 percent in 1989 (Korean Development Bank [KDB] 1971; 1990). And since 1992, the semiconductors have been the top export product of South Korea, accounting for about 12 percent of total export sales (KDB 1999). This is comparable to automobiles, the next top export product in South Korea, which accounts for only about six percent of total export sales (Ibid.). 
TABle 1. The World Leading Semiconductor Firms (1999)*

(Unit: in million dollars)

\begin{tabular}{|c|c|c|c|c|c|c|}
\hline \multicolumn{2}{|c|}{ Rank } & \multirow{2}{*}{ Company } & \multicolumn{2}{|c|}{ Sales } & \multirow{2}{*}{$\begin{array}{c}\text { Growth } \\
\text { Rate }\end{array}$} & \multirow{2}{*}{$\begin{array}{c}\text { Market } \\
\text { Share }\end{array}$} \\
\hline 1998 & 1999 & & 1998 & 1999 & & \\
\hline 1 & 1 & Intel & 22,784 & 26,806 & 13.3 & 15.9 \\
\hline 2 & 2 & NEC & 7,947 & 9,230 & 15.9 & 5.5 \\
\hline 4 & 3 & Toshiba & 5,913 & 7,618 & 28.8 & 4.5 \\
\hline 6 & 4 & Samsung Electronics & 4,743 & 7,325 & 30.2 & 4.3 \\
\hline 5 & 4 & TI & 5,820 & 7,120 & 22.3 & 4.2 \\
\hline 3 & 6 & Motorola & 7,088 & 6,194 & -9.8 & 3.8 \\
\hline 7 & 7 & Hitachi & 4,668 & 5,554 & 19.0 & 3.3 \\
\hline 10 & 8 & Infineon & 3,909 & 5,223 & 33.6 & 3.1 \\
\hline 9 & 9 & ST & 4,899 & 5,077 & 20.9 & 3.0 \\
\hline 8 & 10 & Philips & 4,448 & 5,074 & 14.1 & 3.0 \\
\hline 22 & 11 & Hyundai Electronics* & 1,799 & 4,830 & 168.5 & 2.9 \\
\hline 11 & 12 & Fujitsu & 3,856 & 4,661 & 20.9 & 2.8 \\
\hline 12 & 13 & Mitsubishi & 3,643 & 4,474 & 23.8 & 2.7 \\
\hline 14 & 14 & Lucent Technology & 3,202 & 3,780 & 18.8 & 2.2 \\
\hline 18 & 15 & IBM & 3,234 & 3,520 & 8.8 & 2.1 \\
\hline 20 & 16 & Matsushida & 1,858 & 3,410 & 13.5 & 2.0 \\
\hline 13 & 17 & Micron Technology & 2,634 & 3,214 & 22.0 & 1.8 \\
\hline 16 & 18 & AMD & 2,543 & 2,870 & 12.9 & 1.7 \\
\hline 21 & 19 & Sharp & 1,849 & 2,684 & 45.2 & 1.6 \\
\hline \multirow[t]{3}{*}{17} & 20 & Sanyo & 2,195 & 2,552 & 16.3 & 1.5 \\
\hline & & Others & 40,304 & 47,447 & 17.9 & 28.1 \\
\hline & & Total & 136,686 & 168,672 & 21.6 & 100.0 \\
\hline
\end{tabular}

NOTE: * In 1999, Hyundai Electronics took over LG Semicon, and became Hynix Semiconductors. Also in the following years, a U.S. firm, Micron attempted to take over Hynix but withdrew the plan in May 2002. The data in the table 1 indicates after the merger.

SOURCE: Dataquest (March 2000)

Table 2. Top Ten World Dram Makers, 1999

(Unit: in million dollars, \%)

\begin{tabular}{c|l|r|c}
\hline Rank & & Sales & Market Share \\
\hline 1 & Samsung Electronics & 4,774 & 20.7 \\
\hline 2 & Hyundai Electronics & 4,464 & 19.3 \\
\hline 3 & Micron & 3,330 & 14.4 \\
\hline 4 & NEC & 2,045 & 8.8 \\
\hline 5 & Infineon & 1,680 & 7.3 \\
\hline 6 & Toshiba & 1,505 & 6.5 \\
\hline 7 & Hitachi & 1,114 & 4.8 \\
\hline 8 & Mitsubishi & 875 & 3.8 \\
\hline 9 & Mosel-Vitelic & 600 & 2.6 \\
\hline 10 & Fujitsu & 521 & 2.3 \\
\hline
\end{tabular}




\section{THE ROLE OF THE STATE AND CHAEBOL IN THE DEVELOPMENT OF SOUTH KOREA'S SEMICONDUCTOR INDUSTRY}

This section mainly discusses the development of the semiconductor industry in South Korea focusing on the roles of the state and business groups and changes in their relationship over time. We first examine the early stage of South Korea's semiconductor industry and highlight its limited development and lack of state attention. Then we turn to the cbaebol-initiated industrial transformation of the semiconductor industry in the mid-1980s and show that it was not the state but the private business groups which saw the potential in the semiconductor industry and took courageous steps.

\section{The Beginning of the Semiconductor Industry in South Korea}

The semiconductor industry in South Korea began in the 1960s as subsidiaries of the U.S. semiconductor firms like Fairchild and Motorola. ${ }^{11}$ In 1965, Commy Semiconductors opened business as a subsidiary of an American company, Commy, and began to assemble transistors, and this was the very start of the semiconductor industry in South Korea (The Institute of Industrial Technology Policy [IITP] 1996). Pressured by increasing competition with other U.S. and Japanese rivals, these U.S. semiconductor firms attempted to transfer labor-intensive and low value-added work of simple assembly to developing countries like South Korea and Taiwan where the wage level was relatively low.

However, though such foreign investments provided valuable opportunities for the South Korean firms to participate in the semiconductor industry, the level of technology transferred by these foreign companies was limited to simple assembly. During this early stage, the U.S. and Japanese semiconductor firms largely controlled South Korea's semiconductor industry, as South Korean companies were at the bottom of the hierarchy, simply assembling the finished products. According to S. R. Kim, in this early phase of the development, "Korea was integrated and bound into the world market dynamics, not by the invisible hand of Adam Smith, but by the "visible hand" of the foreign firms" (1996, 12).

When the semiconductor industry was first introduced in South Korea in the mid-1960s, the term semiconductors itself was unfamiliar to many, and the governmental support and interest in the industry was very limited: Except for some general governmental supports on the electronics industry at large, there was no visible industry-level state leadership or assistance. For instance, in 1966, the Park Chung Hee government announced 'Five-Year Plan for Electronics Industry Promotion' and attempted to support the electronics industry as major export sector. ${ }^{12}$ Also, the electronics industry was selected as one of the six target industries ${ }^{13}$ during the Park government's heavy and chemical 
industrialization (HCI) drive in the 1970s. Recognizing the limitation of the light industry and the need to build South Korea's own heavy military armaments, the Park regime attempted to transform the South Korean economy from light to heavy and chemical industry and provided great support to these target sectors.

In fact, the Park regime's HCI drive has been highly recognized as one of the most successful examples of the state-led industrial transformation. In this paper, however, we suggest that one needs to pay closer attention to the variations among "targets," especially in terms of the level of governmental supports and interests. Compared with other target industries such as shipbuilding, steel, and automobiles, it appears that the governmental assistance was somewhat weaker in the case of the electronics. For instance, the Electronics Industry Association of Korea (EIAK) often criticized the inadequate state support and complained that the governmental subsidies and credits were very limited and hardly contributed to the actual development of the industry (EIAK 1990).

Furthermore, the semiconductors were hardly considered a major electronics product. In a total of 229 electronics firms, there were only seven semiconductor firms and all of them were subsidiaries of foreign MNCs and in 1970, the semiconductor industry accounted for only three percent of all electronics companies (KDB 1971). And, unlike other target sectors where state-owned enterprises played a key role, the first wafer-processing production capacity, which requires higher level of technology than simple assembly, was built in 1974 by a private company, Korea Semiconductor Inc. (which later sold to Samsung and became Samsung Semiconductor Inc.) (S. R. Kim 1996).

In short, during this early stage, the state did not have major strategic plans for the semiconductor industry and failed to see the potential in the industry. Also, the level of development and technology of the industry were very limited: Even the big chaebol like Samsung and Goldstar were engaged mainly in labor-intensive, low value-added, and simple assembly work. All parts and components were imported from overseas parent companies and exported back to these advanced countries.

\section{The Erosion of the Developmental State}

Major technological development and leapfrogging of the industry took place when chaebol, especially Samsung began full-fledged participation in the high-tech DRAM business in the early 1980s. Since this period, South Korea's semiconductor industry experienced remarkable growth and transformation into a high technology industry. As Table 3 shows, the percentage of semiconductor devices, which are labor-intensive, requiring relatively low technological skill, declined rapidly over time: In 1983, it accounted for 64 percent of the total production and 
this reduced to only four percent in 1993. On the other hand, the production of memory sector rapidly increased, and by 1993, DRAM accounted for 72 percent of the total production while it was almost non-existent in the early 1980s.

Table 3. Production of South Korean Semiconductors

(Unit: in million dollars)

\begin{tabular}{l|r|r|r|r|r|r}
\hline & \multicolumn{2}{|c|}{1983} & \multicolumn{2}{c|}{1988} & \multicolumn{2}{c}{1993} \\
\cline { 2 - 7 } & Amount & $\%$ & Amount & $\%$ & Amount & $\%$ \\
\hline Semiconductor Devices & 19 & 64 & 132 & 11 & 235 & 4 \\
\hline IC & 7 & 23 & 1,047 & 87 & 4,994 & 95 \\
\hline Memory & - & & 832 & 69 & 4,457 & 85 \\
\hline DRAM & - & & 682 & 57 & 3,785 & 72 \\
\hline Others & 4 & 13 & 26 & 2 & 34 & 1 \\
\hline Total & 30 & 100 & 1,205 & 100 & 5,263 & 100 \\
\hline
\end{tabular}

SOURCE: KSIA (1995)

We propose that unlike other South Korean major industries, semiconductors were mainly promoted and developed by chaebol companies themselves and the industrial transformation in the early 1980s was also brought by the private sector, rather than the state leadership. Then why did the South Korean state fail to lead the transformation of the semiconductor industry in the early 1980s? Before we show chaebol's spontaneous efforts and strategies toward the industry, this section first examines structural factors that weakened and limited the leadership role of the South Korean state.

Indeed, the South Korean developmental state began to show clear signs of erosion from the early 1980s. First, the international political economic factors including the protectionist policies of the U.S. against the South Korean products, South Korea's loss of competitiveness in the labor-intensive products with increasing wages and the rise of China and the Southeast Asian countries, and growing international pressure for economic liberalization, restricted the strong governmental intervention in South Korea. Also, as the Cold War ended in the late 1980s, the U.S. no longer tolerated countries that pursue protectionist economic policies: ${ }^{4}$ Growing U.S. trade deficit with Japan, South Korea, and Taiwan led to increased pressure from Washington for these countries to open their domestic markets.

Since the 1980s, and especially after the late 1980s, South Korea has been seen as a strong rival to many U.S. manufacturing companies. Rising U.S. trade deficit with South Korea prompted the U.S. International Trade Commission to conduct an investigation on DRAMs from South Korea in 1992, and determined that "there is a reasonable indication that an industry in the United States 
is materially injured by reason of imports from the Republic of Korea of dynamic random access memories of one megabit and above $\cdots$ that are alleged to be sold in the United States at less than fair value" (USITC Publication 2519, page 1). The petition was filed by Micron Technology, the world's second biggest DRAM company at the time.

In addition to these international factors, there were important domestic structural factors that brought about the erosion of the developmental state. First, the growth of the chaebol itself threatened the state leadership. The economic power of the chaebol in the South Korean economy increased markedly during the Park Chung Hee period (especially during the $\mathrm{HCI}$ drive) and further intensified throughout the 1980s. On average, the ten largest chaebol grew at an annual rate of 27.7 percent during the 1970s. For instance, Hyundai, the biggest chaebol since the late 1970s and throughout the 1980s, recorded an annual growth rate of 38 percent (E. M. Kim 1997). These chaebols employ a large share of workers and dominate almost every major industrial sector in South Korea (Ibid.). Well equipped with resources and manpower, the chaebol was increasingly in a better position to analyze markets and selecting likely winners than the state.

Changes in the domestic political environment also challenged the state dominance. As the President Park Chung Hee, who had ruled the country for almost two decades, was assassinated in 1979, South Korea no longer had a strong leader with dictatorial power, and the cleavage among politicians grew wider. In 1980, Chun Doo Whan came to power through a military coup but he never obtained a dominant and strong power like Park Chung Hee. ${ }^{15}$ In fact, mainly due to international pressure and popular discontents, the Chun government implemented a series of liberalization measures. Furthermore, with June Declaration in 1987,16 South Korea began democratic transition and massive democratization movements were followed by explosive labor movements. South Korean workers, suppressed for a long time, rose up and demanded labor rights and increase in wages. This growth of civil movements certainly weakened the dominant position of the state over the South Korean society in general. In particular, suppression of labor, which had been a key policy tool of the South Korean developmental state, came under fierce criticism.

Also, the economic stagnation in the early 1980s questioned the efficiency of the state-led economic development path in South Korea. ${ }^{17}$ As one of the main causes of the slow down, the Park government's HCI drive in the 1970s, and its strong state interventionist economic policies were criticized. Under these circumstances, the government was reluctant to invest and support the DRAM business that required a large amount of resources and risky investments. Therefore, unlike the heavy and chemical industries of the 1970s, it was the South Korean chipmakers, not the government, that took the risk and courageously invested in the sector.

Lastly, the South Korea's semiconductor industry was particularly vulnerable 
to the changes in the international market since most of the chips produced in South Korea were exported, and this made the state planning and development of appropriate strategies further difficult. For example, in 1994, 90 percent of the Korean chips were exported. ${ }^{18}$ Also, the South Korea's semiconductor industry was heavily skewed toward the memory sector, and compared to non-memory chips, memory chips were more vulnerable to the changes in the international market environment. Such heavy dependence on the international market and volatile nature of the semiconductor industry also limited the role of the developmental state in the sector.

\section{Toward the World Leading DRAM Makers}

As Table 4 shows, by the early 1990s, all of the three major South Korean chipmakers, Samsung, Hyundai, and LG vigorously expanded their businesses in the global market. Through these active internationalization efforts, the South Korean chipmakers attempted to promote technology transfer and facilitate cooperation with other major chipmakers. Indeed, unlike in the earlier period, many foreign companies now view the South Korean chipmakers as business partners, rather than subsidiaries, and actively seek for technological development and upgrading through close cooperation with them.

Though there were some governmental supports in the semiconductor industry in the early $1980 \mathrm{~s},{ }^{19}$ it was only after Samsung's success in the development of $64 \mathrm{~K} \mathrm{DRAM}$ and 256K DRAM in 1983 and 1984, when the government began to show great interests in the sector. After witnessing Japan's success in the semiconductor industry, the founder of Samsung, Byung Chull Lee, decided to invest in the sector in full scale. Here we mainly focus on Samsung's case since it has been the leading and most successful chipmaker in South Korea and the others largely followed Samsung's leadership.

In the early 1980s, Samsung, like other South Korean major chaebol, was in search of a new business. Increasing competition with other chaebol in the domestic consumer electronics market, well accumulated knowledge in the consumer electronics business, and heavy dependence on the Japanese chips all made Samsung realize the need and importance of the semiconductor chips. In 1974, Samsung merged with Korea Semiconductors Inc. and changed its name to Samsung Semiconductors in 1978. Samsung began with assembly production by importing technology from advanced countries, especially Japan. Up to the early 1980s, its level of technology was very low and limited to simple assembly such as transistors.

However, since around 1982, Samsung began to invest heavily in the high-tech sector, particularly the DRAM. According to S. R. Kim (1996), DRAMs were specifically chosen for the following reasons: (1) DRAMs had relatively large market size compared to other semiconductor products (2) Japanese firms set 
Table 4. Globalization of South Korean Chip Makers

\begin{tabular}{|c|c|c|c|c|}
\hline & Company & Development Product & Investment Relationship & Period \\
\hline \multirow{10}{*}{ Samsung } & Sun Microsystems & Java One & $\begin{array}{l}\text { Comprehensive technological } \\
\text { cooperation (development) }\end{array}$ & 1996. 5 \\
\hline & $\begin{array}{l}\text { DRAM Fab } \\
\text { (Austin, Texas) }\end{array}$ & $\begin{array}{l}16 \mathrm{M}, 64 \mathrm{M} \\
\text { DRAM production }\end{array}$ & $\begin{array}{l}\text { Exclusive Investment } \\
\text { (\$13 billion) }\end{array}$ & 1996.3 \\
\hline & $\begin{array}{l}\text { General Instrument } \\
\text { (GI) }\end{array}$ & $\begin{array}{l}\text { Semiconductors that } \\
\text { are essential to } \\
\text { Multimedia }\end{array}$ & Co-development & 1995.7 \\
\hline & $\begin{array}{l}\text { Integrated Telecom } \\
\text { (IGT) }\end{array}$ & $\begin{array}{l}\text { ATM, Semiconductor } \\
\text { chip }\end{array}$ & Take over ( $\$ 9$ million) & 1995. 1 \\
\hline & Texas Instrument & $\begin{array}{l}\text { Samsung: DRAM } \\
(4 \mathrm{M}, 16 \mathrm{M}) \\
\mathrm{TI} \text { : Logic }\end{array}$ & Co-production & 1994. 1 \\
\hline & \multirow[t]{2}{*}{ Micron Technology } & $\begin{array}{l}\text { Samsung: } 16 \mathrm{MB} \\
\text { Synchronous DRAM } \\
\text { MT: Triple-port } \\
\text { Asynchronous DRAM }\end{array}$ & Second Source & 1993. 11 \\
\hline & & EEPROM, SRAM & Cross License & 1986.6 \\
\hline & General Electric & HDTV chip & Technology/Co-development & 1993. 11 \\
\hline & $\begin{array}{l}\text { Harris Microwave } \\
\text { Semiconductor } \\
\text { (HMS) }\end{array}$ & GaAs & Take over & 1993.5 \\
\hline & Array Microsystems & $\begin{array}{l}\text { Digital Signal } \\
\text { Processor }\end{array}$ & Co-development & 1993. 4 \\
\hline \multirow{4}{*}{$\begin{array}{l}\text { LG } \\
\text { Semicon. }\end{array}$} & Sun Micro & Java Processor Chip & Co-development & 1996.5 \\
\hline & Compass & $0.35 \mathrm{~cm}$ ASIC Library & Co-development & 1995.5 \\
\hline & Sundisk & Flash Memory & Co-development/production & 1995.3 \\
\hline & Rambus & 16M Rambus DRAM & Technology Cooperation & 1994. 4 \\
\hline \multirow{6}{*}{ Hyundai } & $\begin{array}{l}\text { DRAM Fab } \\
\text { (Eugene, Oregon) }\end{array}$ & $\begin{array}{l}16 \mathrm{M}, 64 \mathrm{M} \text { DRAM } \\
\text { production }\end{array}$ & $\begin{array}{l}\text { Exclusive investment } \\
(\$ 13 \text { billion })\end{array}$ & 1996. 2 \\
\hline & $\begin{array}{l}\text { AT \& T GIS } \\
(\text { NCR MPD) }\end{array}$ & $\begin{array}{l}\text { Non-Memory } \\
\text { (ASIC, ASSEP) }\end{array}$ & Take Over ( $\$ 3$ billion) & 1994. 11 \\
\hline & BMI & Flash Memory & Take over & 1993.4 \\
\hline & Micron Technology & Memory IC & Cross License & 1993.3 \\
\hline & IBM & DRAM $(4 \mathrm{M}, 16 \mathrm{M})$ & OEM & 1991 \\
\hline & $\begin{array}{l}\text { Metaflow } \\
\text { Technologies }\end{array}$ & RISC Microprocessor & Take Over & 1991. 11 \\
\hline Anam & Amcor & DRAM (1M, 4M) & Technology Cooperation & 1991.6 \\
\hline
\end{tabular}


a good example that latecomers could also be successful in the DRAMs market and; (3) Compared to other design-intensive products like microprocessors or Application Specific ICs (ASICs), DRAM required a relatively simple design structure. Samsung saw that labor-intensive and low-value added products would soon become uncompetitive in the world market and felt the need to venture into this high-tech sector.

In November 1983, Samsung succeeded in developing 64K DRAM and by 1992, after about a decade since Samsung first started the DRAM business, it became the world's leading DRAM maker. Today, Samsung is the fourth largest semiconductor firm in the world, with sales over 6 billion U.S. dollars (Samsung Semiconductor Homepage). For the DRAM sector alone, Samsung is the largest company in the world, dominating 32.2 percent of the world DRAM market in 2004 (Samsung Semiconductor Homepage).

After the development of $64 \mathrm{~K}$ DRAM in 1983, Samsung succeeded in developing 256K, 1M, and 4M DRAM within following four years. The rise in Samsung's chip sales was also noteworthy; it increased from 244 billion won in 1975 to 122,978 billion won ${ }^{20}$ in 2004 (Samsung Semiconductor Homepage). Along with this remarkable success, Samsung achieved a rapid development in technology. Though Samsung was mainly dependent on foreign technology for the production of $64 \mathrm{~K}$, it developed its own design technology in the case of $1 \mathrm{M}$, and $4 \mathrm{M}$ was built using Samsung's own technology, without any help or borrowing from the outside (Song 1998). Among various factors that contributed to the success of Samsung, in this paper, we stress Samsung's spontaneous efforts and distinctive structural characteristics of the South Korean chaebol as well as favorable international market environments.

Samsung, and other South Korean chipmakers, LG and Hyundai, invested aggressively in the semiconductor industry. In 1980, Samsung invested about 56 billion Korean won and in 2002, the amount increased to 7,840 billion Korean won (Samsung Electronics Homepage 2003), which represented an over one hundred-fold increase in a decade. Indeed, by the late 1980s, the private sector possessed more advanced knowledge and research capability than most of the government research institutes, at least in the DRAM sector. Therefore, over time, the government became dependent on the private sector for up-to-date market and the high-tech information, and this greatly increased the influence and role of the private sector on the governmental policy-making process.

In fact, Samsung's advance in the DRAM business in the early 1980s was not welcomed in South Korea at the time. There was widespread pessimism and many warned that Samsung lacked necessary technology and manpower for the DRAM business, and the government also believed that the industry was too risky and costly. Without any significant governmental support, Samsung borrowed money from foreign banks and financial institutions to build the necessary facilities and promote R\&D. Samsung also transferred the needed capital from 
other profitable business sectors such as telecommunication division as well as from Samsung Electronics Co. using the cross-financing system.

Indeed, the distinctive chaebol structure, which also dominated the South Korean financial sector, provided the Sourh Korean chipmakers with great capital strength that foreign companies were not only competing with Samsung Semiconductors Inc. but also with the giant Samsung chaebol group. With this great capital strength and economic power, the South Korean chipmakers could overcome the hard times and stay in the business when the industry suffered heavy losses. For instance, in 1984, right after Samsung started to export the DRAM, there was a sudden drop in the price of memory chips, and Samsung underwent great losses. The sum of the Samsung's capital investments in 1984 and 1985 exceeded by 300 percent of the total income from semiconductors production (S. R. Kim 1996). Without the inflow of capital from other member firms in other sectors, Samsung would not have been able to continue the semiconductor business.

The other chaebols, Hyundai and LG soon followed suit. However, compared with Samsung, these two latecomers were more cautious in investing in the DRAM business. For instance, in April 1984, LG made a technology transfer contract with an American company, Advanced Micro Devices (AMD) and planned to produce $256 \mathrm{~K}$ DRAM. However, the company postponed the investment period after witnessing Samsung's heavy loss in the DRAM market in 1984. It was not until 1988 when LG finally advanced into 256K DRAM market. Likewise, Hyundai delayed its original plan to produce 256K DRAM until late 1987. In fact, Hyundai and LG at first did not choose DRAM as their major sector. Concerned about fierce competition with Japanese companies in the DRAM, Hyundai selected SRAM and EP Rom instead, and LG was more interested in the non-memory chips (Song 1998). It was around late 1986 and 1987, as the DRAM market was beginning to recover from the downturn when Hyundai and LG started to invest in the DRAM business in full scale.

Favorable international market environments also contributed to the rapid development of South Korea's semiconductor industry. Most of all, the increasing trade dispute between the U.S. and Japanese semiconductor firms offered the South Korean chipmakers a valuable opportunity to advance into, and succeed in the DRAM market. First developed in the U.S., the semiconductor industry has been one of the leading sectors of the U.S. However, by the mid-1980s, Japanese firms emerged as strong rivals and threatened the U.S. dominance over the industry. In response, the U.S. enacted the first Semiconductor Trade Agreement (STA) in 1986. The agreement was valid for five years (1986-1991) and its primary objective was to restrain the dominance of the Japanese companies in the DRAM market and to allow other semiconductor producers to participate in the DRAM business (S. R. Kim 1996). The South Korean chipmakers made best use of this opportunity and saw enormous increases in profits during this 
period.

The year of 1991 was also a lucky year for the South Korean chipmakers. Major Japanese DRAM companies, Toshiba, NEC, and Hitachi stopped building the production line for $1 \mathrm{M}$ DRAM, in preparation for the anticipated upcoming economic downturn. However, with a big hit of Microsoft's Window, there was a boom in the semiconductor market and the computer companies preferred the cheaper $1 M$ DRAM. The price of $1 M$ DRAM rose rapidly as demands exploded and there were no other major producers of 1M DRAM besides the South Korean chipmakers. In addition, the appreciation of the Japanese yen made the Korean chips further competitive. In the following year, Samsung became the top DRAM maker.

The state-business relationship in the development of the South Korea's semiconductor industry was hardly one of the top-down, or leader-follower, and due to structural causes examined in the previous section, the South Korean developmental state began to erode since the early 1980s. Samsung's success in the development of the $64 \mathrm{~K}$ and $256 \mathrm{~K}$ DRAM finally attracted governmental attention and the Chun government created a joint development project of 4M DRAM. All of the major chipmakers, namely, Samsung, Hyundai, and LG, 19 universities, research institutes (including the ETRI), and other small and medium-sized semiconductor companies participated in this project.

Though the Chun government was highly recognized for the success of this project, a closer look at it however questions the leading role of the government. For instance, according to Hong (1997), the Chun government created this joint project at the request of the private sector: The Chairman of Samsung Electronics and Telecommunications, Mr. Jin $\mathrm{Ku} \mathrm{Kang}$, requested state support for the development of 1M/4M DRAMs directly to President Chun in 1986 (S. G. Hong 1997). Furthermore, Samsung, Hyundai, and LG, together accounted for 92 percent of the total research expenses. ${ }^{21}$ Major governmental supports came through the ETRI, a government-sponsored research institute. Instead of leading and directing the chaebol, however, the central role of the ETRI was to coordinate and facilitate cooperation between the chaebol. In many cases, the ETRI depended on the private sector for the current market information and the amount, the kind of governmental support, and long-term plans for the industry were made in close consultation with the chaebol.

Though the governmental support on the industry increased over the years, it could not catch up with the level and speed of the R\&D investment efforts by the private sector. According to Choi (1996), in 1980, the government invested 63.7 percent of the total investment in the field of science and technology and the private sector 36.3 percent. However, in 1987, the government contributed only 24.7 percent and the rest of the investments were made by the private sector. Indeed, the private sector gradually assumed a larger role in R\&D efforts since the early 1980s. For example, for the development of semiconductor devices, 
in 1994, the government invested 50 Korean billion won and the private sector 60 billion Korean won. By 1997, while the amount of governmental support stayed almost the same at around 50 billion Korean won, the private sector investment increased to 90 billion Korean won (S. G. Hong 1997).

\section{CONCLUSION}

In 1999, Hyundai Electronics took over LG Semicon and became Hynix Semiconductor. The merger of these two giant memory chipmakers made Hynix the second largest DRAM company after Samsung. This merger was in large part due to the Asian financial crisis in 1997-1998. The Kim Young Sam government had to ask for the bailout from the IMF in November 1997 and the chaebol were highly criticized for their high debt and mismanagement. The merger followed the procedures initiated as part of the government's Big Deal program. Big Deal is a corporate asset-swapping plan that was central to Kim Dae Jung government's chaebol reform plan after the crisis. As a part of the Big Deal, LG gave up its semiconductor business to Hyundai.

The internationalization and liberalization of the South Korean economy have been accelerating since the crisis, further weakening the traditional role of the developmental state. Through a case study of South Korean semiconductors, this paper examined the limitations of the state-centered approach in understanding South Korea's rapid development. Questioning the role of the South Korean state, we have shown that the semiconductor industry did not exactly follow the typical path of the developmental state model of the 1970s and 1980s.

While recognizing the limitations of the developmental state, we are not however, discarding the whole developmental state model. It is almost impossible to explain the economic development of South Korea without recognizing the role of the state and we wanted to make it clear that it is one thing to note the erosion of the developmental state and another to argue that such erosion is the answer for the future of the South Korean economy. We also recognize the limitation of this study; as it focused only on the semiconductor industry, it would be hasty to generalize the argument made in this study. What we have emphasized here, however, is that in the case of the semiconductor industry, the private sector has been in the driver's seat, leading the industry, and sometimes pressuring the state. This finding challenges the notion of South Korea's 'strong state, weak society' model which has been envied and followed by many less advanced countries.

With encroaching pressure of economic globalization, especially after the 1997-1998 Asian financial crisis, the South Korean market has experienced a rapid integration with the world market and the idea of state-led economy seems to have become out-of-date. With the breakout of the Asian financial 
crisis, many criticized the developmental state model as the main cause of South Korea's fall and the Korean economy has undergone drastic liberalization and deregulation. It is clear that the developmental state framework of the past has undergone a fundamental transformation. Questions for future research then, include: What are the new roles of the South Korean state in the economy? Has the Korean state become a regulatory state as suggested in the neoclassical literature? If not, what is the nature of this newly transformed state and how does it affect the political economy of South Korea?

\section{REFERENCES}

Amsden, Alice H. 1989. Asia's Next Giant: South Korea and Late Industrialization. New York and Oxford: Oxford University Press.

Amsden, Alice H. 1994. The Specter of Anglo-Saxonization Is Haunting South

Korea. in Cho and Kim (eds) Korea's Political Economy: An Institutional Perspective. Westview Press, Part II, 87-127.

Cheng, Tun-jen. 1990. Political Regimes and Development Strategies: South Korea and Taiwan. in Gary Gereffi and Donald L. Wyman (eds) Manufacturing Miracles: Paths of Industrialization in Latin America and East Asia. Princeton, NJ: Princeton University Press, 139-78.

Cho, M. H. 1994. Semiconductor Industry (in Korean). Seoul: Ungjin Press.

Choi, Y. H. 1996. The Path to Modernization 1962-1992. in Branscomb and Choi (eds) Korea At The Turning Point: Innovation-Based Strategies for Development, Westport. Connecticut and London: Praeger.

Chosun Ilbo. Various issues.

Choung J., Hwang H., and Choi, J. 2000. Transition of Latecomer Firms from Technology Users to Technology Generators: Korean Semiconductor Firms. World Development 28(5): 969-982.

Chung, K. H., Lee, H. C., and Jung, K. H. 1997. Korean Management: Global Strategy and Cultural Transformation. Berlin and New York: Walter de Gruyter. Cumings, Bruce. 1984. The Origins and Development of the Northeast Asian Political Economy: Industrial Sectors, Product Cycles, and Political Consequences. International Organization 38(1): 1-40.

Dataquest. Various issues.

Dittmer, Lowell. 2000. Globalization and the Asian Financial Crisis. in S. S. Kim (eds) East Asia and Globalization. Lanham, Boulder, New York, Oxford: Rowman \& Lottlefield Publishers, Inc.

Doner, Richard F. 1992. Limits of State Strength: Toward an Institutionalist View of Economic Development. World Politics 44.

EIAK. 1990. Thirty Years' History of the Electronics Industry (in Korean). Seoul: EIAK. 
Evans, Peter. 1994. Predatory, Developmental, and other Apparatuses. in Kincaid and Portes (eds) Comparative National Development: Society and Economy in the New Global Order. Chapel Hill: The University of North Carolina Press, pp. 84-111.

Evans, Peter. 1995. Embedded Autonomy: States E Industrial Transformation. Princeton University Press.

Fields, K. J. 1995. Enterprise and the State in Korea and Taiwan. Ithaca and London: Cornell University Press.

Haggard, Stephan, and Cheng, Tun-jen. 1987. State and Foreign Capital in the East Asian NICs. In Deyo (ed.) The Political Economy of the New Asian Industrialism. Ithaca and London: Cornell University Press.

Haggard, Stephan and Moon, Chung-In. 1990. Institutions and Economic Policy: Theory and a Korean Case Study. World Politics 42(2): 210-237.

Heo, Uk and Kim, Sunwoong. 2000. Financial Crisis in South Korea: Failure of the Government-Led Development Paradigm. Asian Survey 40(3): 492-507.

Hobday, Mike. 1995. East Asian Latecomer Firms: Learning the Technology of Electronics. World Development 23(7): 1171-1193.

Hong, S. G. 1997. The Political Economy of Industrial Policy in East Asia: The Semiconductor in Taiwan and South Korea. Cheltenham, UK: Edward Elgar Publishing Inc.

Hyundai Electronics Co. (HEC). 1994. Company Material. Seoul: HEC.

Institute of Industry Technology Policy (IITP). 1996. Development of the industrial Technology toward the year 2000: The Semiconductor Industry (in Korean), Seoul: IITP.

Johnson, Chalmers. 1982. MITI and the Japanese Miracle. Stanford, CA: Stanford University Press.

Kim, Samuel. 2000. Electoral Politics and Economic Crisis, 1997-1998. In Consolidating Democracy in South Korea. eds. Larry Diamond and Samuel Kim. Boulder, CO: Lynne Reinner.

Kim, E. M. and Chang, D. 2001. From Hierarchies to Markets?: Korea's Corporate Restructuring After the Asian Crisis of 1997. Paper presented at the American Sociological Association annual meeting in August 2001.

Kim, E. M. 1988. From Dominance to Symbiosis: State and Chaebol in Korea. Pacific Focus 3(2): 105-21.

Kim, E. M. 1997. Big Business, Strong State: Collusion and Conflict in South Korean Development, 1960-1990. State University of New York Press.

Kim, Linsu. 1993. National System of Industrial Innovation: Dynamics of Capability Building in Korea. In Nelson (ed.) National Innovation System: A Comparative Analysis. New York and Oxford: Oxford University Press.

Kim, Linsu. 1997. The Dynamics of Samsung's 'Technological Learning in Semiconductors. California Management Review 39(3): 86-100.

Kim, M. K. 1996. The Government-Relations in the Semiconductor Industry: 
for the Proper Industrial Policy. Association of Korean Policy Making 5(1).

Kim, S. Ran. 1996. The Korean system of innovation and the semiconductor industry: a governance perspective. SPRU/SEI-Working Paper.

Korean Development Bank (KDB). 1971, 1976, 1984, 1987, 1990, 1993, 1999. Industry in Korea, Seoul: KDB.

The Korea Economic Daily. October 24, 1998.

Korea Exchange Bank Homepage. 2004. Foreign Exchange Rate. http://unww.keb.co.kr Korea Semiconductor Industry Association (KSIA). 1995. 21 Sekireul Hyanghan Bandocbesaneupue Baljeonrayk [The Development Strategy for the Korean Semiconductor Industry Toward the 21st Century]. Seoul: KSIA.

KOTIS. Various Issues.

Lee, C. W. 2000. Chaebol Gyebyuk [Chaebol Reform]. Seoul: Joheunkeul.

Lee, S. C. 1991. The Heavy and Chemical Industries Promotion Plan (1973-79). in Cho and Kim (eds) Economic Development in the Republic of Korea: A Policy Perspective, An East-West Center Book, University of Hawaii Press: pp. 431-473. Lim, 2001. Market-Led Corporate Restructuring in State-Led Economy: A Problem of Transition. paper presented for Korea' Economy at 2001, published by the Korea Economic Institute of America.

Ministry of Science and Technology. 1996. Korea Electronics Yearly (in Korean). Seoul: Ministry of Science and Technology.

Mo, J. and Moon, J. 1999. Korea After the Crash. Journal of Democracy 10(3): 150-164.

Moon, Chung-In. 1988. The Demise of a Developmental State? Neoconservative Reforms and Political Consequences in South Korea. Journal of Developing Societies 4.

Samsung Electronics Co. (SEC). 1999. Company Material. Seoul: SEC.

Samsung Electronics Homepage. 2004. Financial Overview 2002. http://www.sec.co. kr/images/corp/business/annualreport/annual_2002_financial_overview.pdf

Samsung Semiconductor Homepage. 2004. Top 10 DRAM Companies. bttp:/lorigin. samsung.com/Products/Semiconductor/DivisionPolicy/AboutourDivision/BusinessPerform ance.htm

Samsung Semiconductor Homepage. 2004. Top 10 Semiconductor Companies. bttp:// origin.samsung.com/Products/Semiconductor/DivisionPolicy/AboutourDivision/Business Performance.htm

Shin, Doh C. 1999. Mass Politics and Culture in Democratizing Korea. Cambridge, UK: Cambridge University Press.

Smith, David A. 1997. Technology, commodity chains and global inequality: South Korea in the 1990s. Review of International Political Economy 4(4).

Song, S. S. 1998. The Growth of Samsung's Semiconductor Sector and the Development of Technological Capabilities. Korean Science History Papers 20(2). USITC. 1992. DRAMs of One Megabit And Above From the Republic of Korea. 
Wade, Robert. 1990. Industrial Policy in East Asia: Does it Lead or Follow the Market?. in Gereffi and Wyman (eds) Manufacturing Miracles: Paths of Industrialization in Latin America and East Asia. Princeton, NJ: Princeton University Press: pp. 231-267.

Yoon, C. H. 1986. Bandoeche Sanupui Hyunbwang gua Yookseong Jeongchaek [An Analysis of the South Korea's Semiconductor Industry and Governmental Promotion Policy], Seoul: Korean Economic Research Institute.

\section{ENDNOTES}

1 Most of the early studies of the developmental state model were conducted in the 1980s and early 1990 s following Chalmers Johnson (1982)'s study of the Japanese MITI. One of the main reasons that these studies heavily focus on the state was because they needed to defend the utility of the developmental state model from the severe attack by the neo-classical approach.

2 In particular, the author emphasized the role of the Korea Institute of Electronics Technologies (KIET), a public research institute. Established in 1976, the KIET was mainly responsible for R\&D, importation, technical assistance, exportation, disseminating foreign technologies, etc. It was renamed in 1984 as the Electronics and Telecommunications Research Institute (ETRI).

${ }^{3}$ Chaebol indicates big business groups in South Korea. It is a type of a business organization that is typically owned by a family and each chaebol has a group of companies.

4 See Cheng (1990) for more detailed comparative analysis on the economic structure of South Korea and Taiwan.

5 According to Evans (1995), a developmental state not only needs a relative autonomy from the society but also embeddedness to other social actors in order to successfully pursue its economic policies.

6 "Custodial" role indicates regulatory efforts that highlight policing; "Demiurge" refers to a specific way of playing the role of producer; "Midwifery" indicates where the state assists the emergence of new entrepreneurs in more challenging industrial sector and; "Husbandry" consists of cajoling and assisting private business groups in hopes of meeting the challenges they face when these business groups participate in the promising business sectors. For more about the state roles, see Chapter 1 and 3 of Evans (1995).

${ }^{7}$ Semiconductor industry has great ripple effects on other electronics products, including multimedia and information communication.

8 Around 82 percent of the South Korean semiconductor products are memory chips while they account for only about 20 percent of the world semiconductor market - non-memory chips account for the other 80 percent (Korea Semiconductor Industry Association [KSIA] 1999). Compared to memory chips, non-memory chips are more difficult to copy. Also, while the production technology is important for the memory chips, the non-memory chips require a high level of design technology. Therefore, as far as the firm maintains the design technology know-how, the non-memory chips often results in a higher value added than the memory chips. For more information about the semiconductor chips and the technical difference between the memory and the non-memory chips, see KSIA 1999.

9 According to a survey by Chosun Ilbo, 48 percent of the respondents (119 foreign businessmen in South Korea) chose the semiconductors as the most competitive product in South Korea (Chosun Ilbo June 23, 1996).

${ }^{10}$ In the semiconductor industry, it is critical to maintain and continue to develop new technology since the first that succeeds in producing new chips dominates most of the gains: This is mainly because manufacturers produce and model their products based on the chips that are first developed. Therefore, it is also important to calculate the right timing of the chip-production.

${ }^{11}$ Fairchild came to Korea in 1966 and Motorola in 1967.

${ }^{12}$ Also in 1979, the government announced the 'Eight-Year Plan for Electronics Industry Promotion (1969-76)'. This Plan had three major goals: 1) developing 95 major electronic items (semiconductors being one of them), 2) exporting 400 million dollars worth of products by 1976, and 3) forming 14 billion won of Promotional Fund (S. G. Hong 1997).

${ }^{13}$ Six target industries include the automobile, steel, nonferrous metal, shipbuilding, industrial machinery, electronics, and petrochemical industries.

${ }^{14}$ During the Cold War, the US provided the capitalist allies in East Asia, including Japan, Hong Kong, South Korea, and Taiwan with favorable economic opportunities. An extensive amount of 
the US foreign aid was given to South Korea and Taiwan, making it possible for these countries to begin their export-led growth. Also, the US opened its own market to these countries and tolerated their continued discrimination against dollar exports.

${ }^{15}$ The opposition party was stronger and when Chun came to power, he promised that he would only serve for seven years and kept his promise.

${ }^{16}$ June Declaration includes 8-point pledge. They are: (1) the amendment of the constitution for the direct election of the president, (2) the revision of the presidential election law to ensure the freedom of candidacy and fair competition in direct popular elections, (3) the granting of amnesty to Kim Dae Jung and other political prisoners and allowing them to resume political activities, (4) the protection of human dignity and promotion of basic rights, including an unprecedented extension of the Writ of Habeas Corpus, (5) restoring freedom of the press by abolishing the repressive Basic Press Law, (6) the institution of educational autonomy and local self-government through the popular election of local assemblies and executive heads of local governments, (7) the creation of a new political climate for dialogue and compromise especially among competing political parties, and (8) carrying out bold social reforms to build a clean, honest society and to promote a secure, happy life (Shin $1999,3)$.

${ }^{17}$ During the period of 1979-81, the average growth rate was mere 2.5 percent and in 1980 , it recorded -4.9 percent. This is a drastic drop of economic growth compared to previous decade when South Korea recorded average growth rate of about 12 percent.

${ }^{18} 33 \%$ of these went to the US, 32\% to Asia, 20\% to EU, and 15\% to Japan (IITP 1996).

${ }^{19}$ For instance, in 1982, the Chun government announced the 'Semiconductor Industry Promotion Plan' and provided the industry with lower interest rates, tax exemptions, and lower tariffs on the semiconductor devices. For more about the governmental support of the semiconductor industry during the early 1980s, see M. K. Kim 1996, 224-226 and S. G. Hong 1993, 730-733.

${ }^{20}$ Exchange rate from the Korea Exchange Bank as of June 25, 2004 was applied to convert the U.S. Dollars to the Korean Won. The original figure is $\$ 10,502$ million (KEB).

${ }^{21}$ By the way, through this joint project, Hyundai and LG could get technology transfer from Samsung. 